\title{
Impact of drought and stand edge on mycorrhizal density on the fine roots of Norway spruce
}

\author{
V. Pešková, F. Lorenc, R. Modlinger, V. Pokorná
}

Pešková V., Lorenc F., Modlinger R., Pokorná V., 2015. Impact of drought and stand edge on mycorrhizal density on the fine roots of Norway spruce. Ann. For. Res. 58(2): 245-257.

Abstract. This paper evaluates the mycorrhizal status and root system of Norway spruce (Picea abies (L.) Karst.) with respect to trees' position within the stand and artificially induced drought stress. Root systems were sampled during autumn of 2008, 2009 and 2013 from spruces exposed to varying conditions (totalling 18 trees, 47 samples). The experiment involved six groups of three spruces each. Three groups were growing within the stand and three groups at the stand's edge. One tree from each group (total 6) was exposed to artificial drought using shelters deflecting rainfall away from the root system. For each sample, the number of active and non-active mycorrhizae on 20 root segments about $5 \mathrm{~cm}$ long was assessed. The densities of active and non-active mycorrhizae, proportion of active mycorrhizae, and root dry biomass weight were assessed. Factors' significances were determined using ANOVA and the Tukey-Kramer test or the KruskalWallis and Dunn's tests. Samples from outside the sheltered area were characterized by higher numbers of active mycorrhizae than were those sampled within the sheltered area. Induced drought stress significantly influenced active mycorrhizae density. Significantly higher root dry biomass (roots $<1 \mathrm{~mm}$ in diameter) was found at the stand's interior versus its edge. Keywords Ectomycorrhizae, Picea abies, stress, biomass, root system precipitation.

Authors. Vítězslava Pešková (peskovav@fld.czu.cz), František Lorenc, Veronika Pokorná - Czech University of Life Sciences Prague, Faculty of Forestry and Wood Sciences, Kamýcká 129, 16521 Prague 6 - Suchdol, Czech Republic; Roman Modlinger - Forestry and Game Management Research Institute, Strnady 136, 15604 Praha 5 - Zbraslav, Czech Republic.

Manuscript received November 13, 2014; revised April 09, 2015; accepted April 14, 2015; online first April 20, 2015.

\section{Introduction}

Mycorrhizal symbiosis is a very important ecophysiological trait in the majority of higher forest plants, including important woody species. The roots of woody species in temperate zones acquire ectomycorrhizae, which embody a characteristic mycorrhizal symbiosis 
with specific fungi species. The majority of ectomycorrhizal roots present a characteristic anatomy and their outstanding feature consists in physiological activities derived from both components in the relationship, the mycobiont and the phytobiont (Peterson et al. 2004). The most important ecological characteristic of mycorrhizal symbiosis derives from specific properties of the mycelia, whose large surface area enables contact with a greater number of soil particles. Mycorrhizae are capable of better receiving and accumulating mineral nutrients from soil (Gryndler et al. 2004). Plants with well-developed mycorrhizal systems show increased resistance to unfavourable environmental conditions (e.g. low temperature, drought, $\mathrm{pH}$ changes, and toxins), and they are also resistant to attacks from parasites and root pests (Mejstř́ík 1989, Pešková 2008). Mycorrhizal symbiosis is of great importance for the host plant's water supply, especially during periods of water shortage (Gryndler et al. 2004). The ecological significance of the ectomycorrhizal fungi species is correlated to the mycorrhizal process, particularly the number of mycorrhizal tips (Landeweert et al. 2003). The vertical distribution of mycorrhizae in soil is not even. In boreal forests, two-thirds of root tips occur in the mineral soil horizon and half are connected exclusively to these horizons (Rosling et al. 2003). In Norway spruce, the number of ectomycorrhizal tips mainly increases with soil depth, while the number of both non-vital tips and vital non-mycorrhized tips decreases with soil depth (Scattolin et al. 2008). The biomass of active ectomycorrhizal fine roots and extramatrical mycelium depends on stand age and forest development phase. It has been estimated that the mycelium biomass of ectomycorrhizal fine roots in forest ecosystems amounts to $20-10,000 \mathrm{~kg} \mathrm{ha}^{-1}$ (Cairney 2012, Kałucka \& Jagodziński 2013). Physiological studies have shown an increase in the root dry biomass of plants associated with appropriate fungal species. The increase in dry biomass has been observed considerably to affect plants growing on soils with low nutrient content or containing mineral nutrients in unavailable forms (Mejstř́k 1988).

Mycorrhizal development is greatly influenced by environmental factors, host plant, the symbiotic fungi's physiology, and interactions with other soil micro-organisms. These factors are interconnected and must be considered as a complex system (Mejstrík 1989). Water fundamentally affects growth of the mycelium of ectomycorrhizal fungi, and water supply is vital also for fruit body growth. It is well known that drought substantially limits fructification, i.e. fruit body production (Gryndler et al. 2004). Mycorrhizal fungi principally produce fruit bodies after heavy rains, as rainwater soil leaching is an important water source for many ectomycorrhizal fungi (Mehus 1986, Gryndler et al. 2004). Sufficient precipitation during fructification (in autumn) positively and considerably affects fungal fruit body growth. It is affected also by spring precipitation, however (Salerni et al. 2002).

Abiotic stresses, including drought, may greatly influence the interaction among host plants, symbiotic micro-organisms (including mycorrhizal fungi), and insect herbivores (Pineda et al. 2013). Drought has been shown significantly to change the species composition of mycorrhizal fungi established on short roots (as indicated by identified morphotypes and DNA sequencing) (Shi et al. 2002). The proportion of active mycorrhizae within a given locality probably responds to such immediate changes as moisture stress and emissions of $\mathrm{SO}_{2}, \mathrm{NO}_{\mathrm{x}}$ and heavy metals (Pešková et al. 2007, Šrámek et al. 2009). A rise in soil temperature leads also to a general increase in root tips and ectomycorrhizae. Various ectomycorrhizal fungi species nevertheless respond differently to soil temperature, because they have different optimal temperatures (Domisch et al. 2002). Studies on fine roots and mycorrhiza responses to drought may yield useful information about damage caused by drought. For the purposes of such studies, data as to number 
of root tips, fine root density or dry biomass, and root length could be used more frequently (Cudlin et al. 2007). Tree response to environmental conditions may be affected by tree size. Sensitivity to climate among shade-intolerant and moderately shade-tolerant species (e.g. Norway spruce - Picea abies (L.) Karst.) remains constant between size-diameter classes for temperature balance and hydric balance. In contrast, shade-tolerant species show significant differences, with larger trees being more sensitive to summer drought than are smaller trees. Moreover, this difference increases with intensifying climatic xericity (Mérian \& Lebourgeios 2011). P. abies stands exposed to short- or long-term droughts have been observed to display lower vitality and greater susceptibility to pest infestation (Økland \& Berryman 2004) and to root infection by primarily parasitic wood-decay fungi (DesprezLoustau et al. 2006, Lindner et al. 2008).

Most experiments, concerned with the relationship between water regime and ectomycorrhizae have been short-term, including only one dry season (Feil et al. 1988, Palátová 2004, Lehto \& Zwijazek 2011). The relationship between water regime and ectomycorrhizae for Norway spruce seedlings grown under artificial conditions has been studied by Möttönen et al. (2001, 2005) and Nilsen et al. (1998). The influence of irrigation under artificial and natural conditions during a single year has been studied by Feil et al. (1988), and the impact of repeated irrigation under natural conditions has been examined by Fransson et al. (2000). The effect of artificial drought stress on mycorrhizal relationships was established by Lorenc (2012) in 80-year-old spruce stands on two research plots, both of which were divided into sheltered (stressed by artificial drought) and control sites.

The relationship between trees' position within the stand and mycorrhizal system density for Norway spruce has not yet been fully resolved. Meanwhile, the role of ectomycorrhizae during extended and repeated dry sea- sons under natural conditions is practically unknown.

The aim of this paper was to establish whether artificially induced water deficits produced changes in mycorrhizal parameters and whether these relationships were affected by trees' position within the stand.

\section{Methodology}

The effects of drought and stand position on mycorrhizae and fine roots of Norway spruce were assessed in research plots in the Brdy mountains (Central Bohemia, Czech Republic, $49^{\circ} 40^{\prime} 45.6^{\prime \prime} \mathrm{N}, 13^{\circ} 56^{\prime} 10.6^{\prime \prime} \mathrm{E}, 650 \mathrm{~m}$ a.s.1.). Mean temperature is around $9{ }^{\circ} \mathrm{C}$ and annual mean precipitation is $527 \mathrm{~mm}$ (Nádrazská et al. 2011, Zajíčková et al. 2011). Research plots were situated in a Norway spruce monoculture stand which had reached the age of approximately 80 years at the start of the research. The stand was evenly canopied and displayed no noticeable damage. Mycorrhizae and fine roots were assessed in six groups of three spruces each (totalling 18 trees) in a plot design which was designated as P1-P6 (see Fig. 1 and Table 1). Plots P1-P3 were within the stand and plots P4-P6 were situated at the stand's edge. The plots' water regime was modified in 2008 and 2009 by the construction of shelters which drained rainwater out of the research plots (Zajíčková et al. 2011).

Roots and mycorrhizae were sampled from each of the 18 trees on 9 October 2008, 26 October 2009, and 5 November 2013. Samples were taken by means of a root auger with inner diameter of $6 \mathrm{~cm}$ to a depth of $15 \mathrm{~cm}$. Samples were stored in a cold room until processing. Soil sample processing included root extraction, whereby spruce roots were manually removed from the soil using tweezers and dissecting needles. The selected roots were measured by diameter on graph paper and then classified into 4 groups based on diameter: $<1$ $\mathrm{mm}, 1-2 \mathrm{~mm}, 2-5 \mathrm{~mm}$, and $>5 \mathrm{~mm}$. 


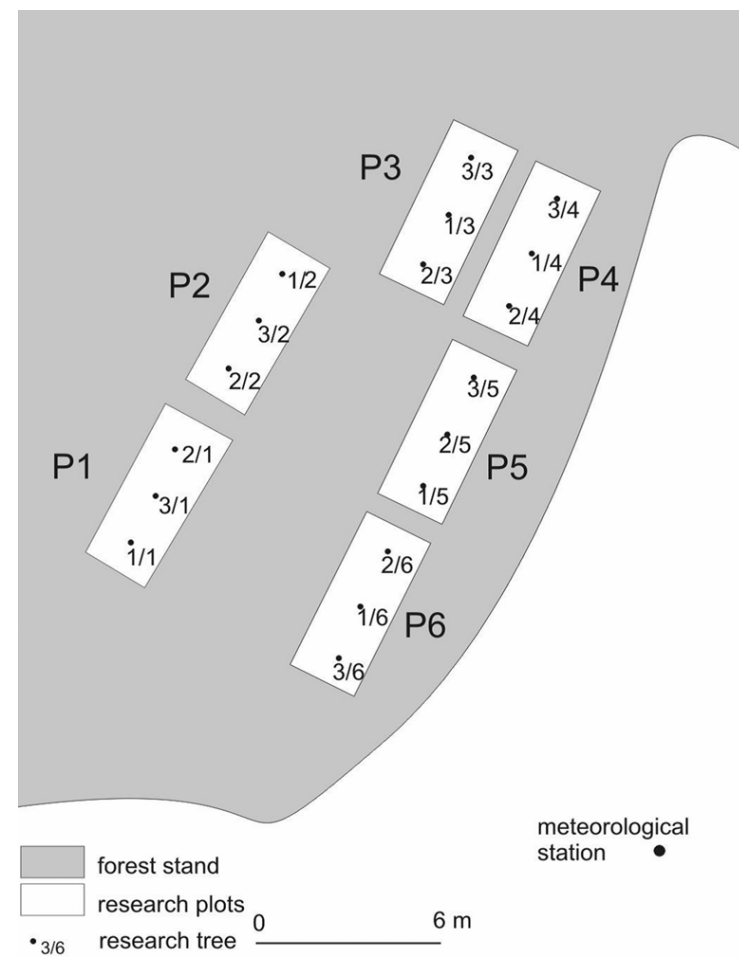

Figure 1 Research plots (based upon Nádraská et al. 2011)

Roots $<1 \mathrm{~mm}$ were placed into glutaraldehyde fixing solution. Mycorrhizae were assessed following the method detailed by Pešková \& Soukup (2006). Mycorrhizae were assessed on roots with diameters $<1 \mathrm{~mm}$, as only these roots were most responsive to environmental changes while roots with larger diameters could not be sampled by the auger in a representative manner (Mejstrík 1988, Kocourek 1991). Twenty root segments with main root length of $5 \mathrm{~cm}$ were randomly selected from each sample. The total length of each segment was determined as equal to the main root length plus the root length of its branching systems. Subsequently, mycorrhizae on each root segment were counted under a stereomicroscope at 40x magnification and classified as active or non-active apices. Tips lighter in colour, with a smooth surface, lacking radical hair, with high turgor pressure and developed hyphae sheathes were classified as active mycorrhizae. Darker, 248 wrinkled tips with markedly less turgor pressure and without hyphae sheathes were classified as non-active mycorrhizae (Kocourek 1991). The level of mycorrhization was assessed using the parameters mycorrhizae density and proportion. Densities of active (ActM) and non-active (NactM) mycorrhizae were calculated as the average value of mycorrhizae associated with $1 \mathrm{~cm}$ of root length. Another parameter was the relative proportion of active mycorrhizae (\% ActM) (Caisová 1994). Root dry biomass relative $(<1 \mathrm{~mm})$ to soil sample volume was also taken into consideration.

Mixed soil samples from each plot (totalling 6 samples) were prepared to establish soil $\mathrm{pH}$. Soil $\mathrm{pH}$ values were measured using two methods: in a water solution and in a $\mathrm{KCl}$ solution (ISO/DIS 10390 1992). The data obtained was assessed using NCSS 8.0 statistical software. Individual variables and their interactions were tested for their correspondence to the Gaussian 
Table 1 Number of root samples in individual years

\begin{tabular}{llcccc}
\hline & & 2008 & 2009 & 2013 & Total \\
\hline Location & 1 & 3 & 0 & 3 & 6 \\
& 2 & 3 & 3 & 3 & 9 \\
& 3 & 3 & 3 & 3 & 9 \\
& 4 & 3 & 3 & 2 & 8 \\
& 5 & 3 & 0 & 3 & 9 \\
& 6 & 3 & 12 & 17 & 6 \\
& Total & 18 & 6 & 9 & 47 \\
\hline \multirow{5}{*}{ Position } & Within & 9 & 6 & 8 & 23 \\
& Edge & 9 & 12 & 17 & 47 \\
& Total & 18 & 6 & 0 & 12 \\
& Yes & 6 & 6 & 17 & 35 \\
& No & 12 & 12 & 17 & 47 \\
\hline
\end{tabular}

distribution using the Shapiro-Wilk test, as is typical for that purpose (Hintze 2007). When data reasonably conformed to the normal distribution, analysis of variance (ANOVA) and subsequently Tukey's multiple comparison test were used. When the test of normality was not satisfied, the Kruskal-Wallis $(\mathrm{K}-\mathrm{W})$ and non-parametric Dunn's multiple comparison tests were used (Hintze 2007).

\section{Results}

Statistically significant differences (ANOVA: $N=47, d f=2, F=22.91, p<0.001$, Fig. 2) in active mycorrhizae density across observation years were established. Mycorrhizae were determined to be most active in 2013, which year differed significantly from the others (TukeyKramer: $N=47, d f=44, p<0.05)$. Statistically significant annual differences in non-active mycorrhizae also occurred (ANOVA: $N=47$, $d f=2, F=92.91, p<0.001$, Fig. 2). The year 2009 had the largest proportion of non-active mycorrhizae, and this was a statistically significant difference from the other years (Tukey-Kramer: $N=47, d f=44, p<0.05)$. The lowest active as well as inactive mycorrhizae densities were determined in 2008. Significant annual differences were observed for active mycorrhizae proportions (ANOVA: $N=47, d f$ $=2, F=51.45, p<0.001$, Fig. 2). Active mycorrhizae proportions fluctuated substantially over the monitored years and all the compared years were different (Tukey-Kramer: $N=47$, $d f=44, p<0.05)$. Annual differences in fine root biomass (diameter $<1 \mathrm{~mm}$ ) was also significant (ANOVA: $N=47, d f=2, F=13.86, p$ $<0.001$, Fig. 2), and this was probably caused by the statistically significant dissimilarity between 2008 and all the other years (TukeyKramer: $N=47, d f=44, p<0.05$, Fig. 2). The results of all analyses are summarized in Table 2 and mean values of individual factors are in Table 3. Soil from the research plots was highly acid (mean $\mathrm{pH}$ values were 3.79 in the water solution and 3.28 in the $\mathrm{KCl}$ solution).

More active mycorrhizae were found in samples collected outside the sheltered areas than in those from within the sheltered areas. These differences were statistically significant (K-W: $N=47, d f=1, p<0.05$, Fig. 3 ). A similar trend was established in the number of non-active mycorrhizae, but the differences were not significant due to this parameter's considerable dispersion $(\mathrm{K}-\mathrm{W}: N=47, d f=$ $1, p>0.05$, Fig. 3). The mean proportions of active mycorrhizae were similar for both vari- 
ants, as well as in the case of the weight of roots with diameters $<1 \mathrm{~mm}$. Differences were not statistically significant for either the active mycorrhizae proportion (K-W: $N=47, d f=1$, $p>0.05$, Fig. 3) or for the weight of roots with diameters $<1 \mathrm{~mm}$ (ANOVA: $N=47, d f=1, F$ $=0.60, p>0.05$, Fig. 3).

Soil probes taken within the stand exhibited
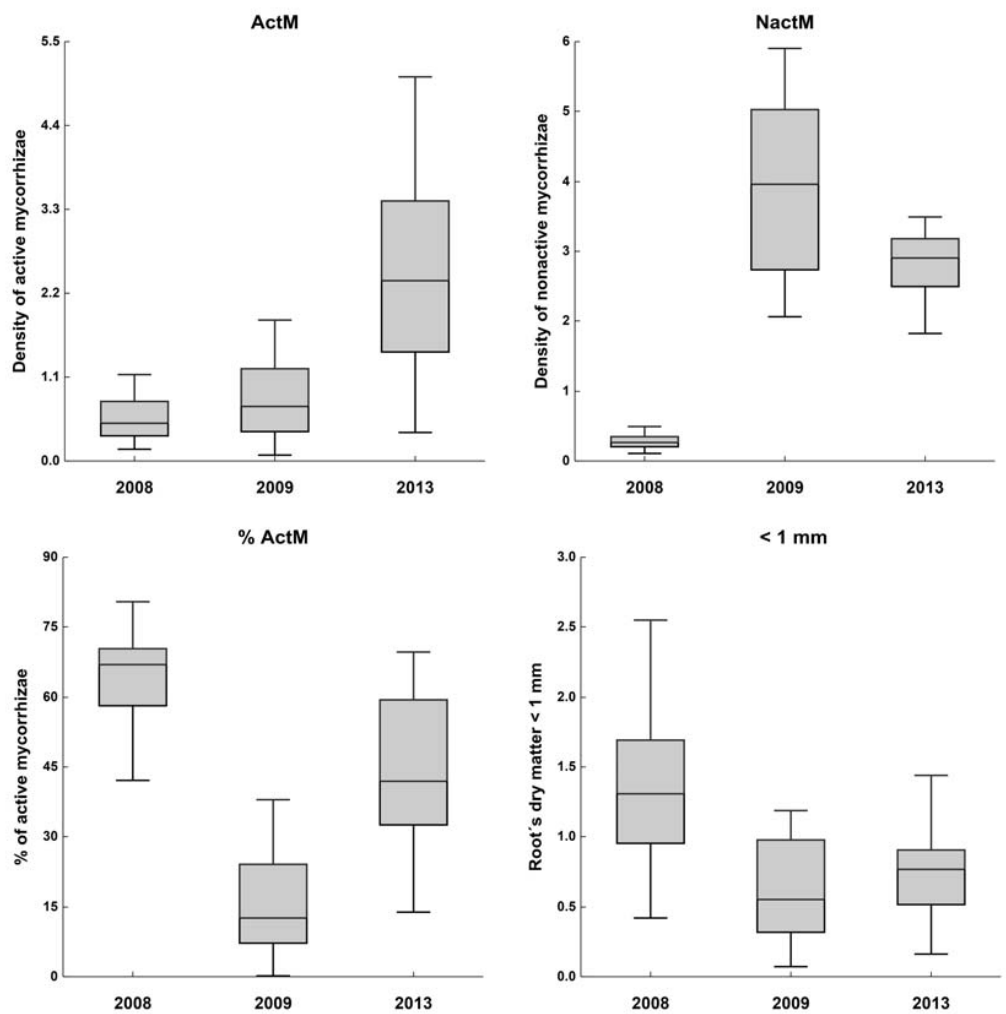

Figure 2 Box plots of mycorrhizal parameters and root dry matter $(<1 \mathrm{~mm})$ in 2008, 2009, and 2013 (median - central band, box $-1^{\text {st }}$ and $3^{\text {rd }}$ quartile, whiskers -1.5 multiple of interquartile range)

Table 2 Summary of test results for significance of factors influencing mycorrhizae development

\begin{tabular}{|c|c|c|c|c|c|c|}
\hline & $N$ & $D F$ & Actm & NactM & $\%$ ActM & $R<1 \mathrm{~mm}$ \\
\hline Year & 47 & 2 & $\begin{array}{l}\mathrm{F}=22.91 \\
p<0.001 * * * \\
\text { ANOVA }\end{array}$ & $\begin{array}{l}\mathrm{F}=92.91 \\
p<0.001 * * * \\
\text { ANOVA }\end{array}$ & $\begin{array}{l}\mathrm{F}=51.45 \\
p<0.001 * * * \\
\text { ANOVA }\end{array}$ & $\begin{array}{l}\mathrm{F}=13.86 \\
p<0.001 * * * \\
\text { ANOVA }\end{array}$ \\
\hline Sheltered & 47 & 1 & $\begin{array}{l}p<0.05 * \\
\mathrm{~K}-\mathrm{W}\end{array}$ & $\begin{array}{l}p>0.05 \\
\mathrm{~K}-\mathrm{W}\end{array}$ & $\begin{array}{l}p>0.05 \\
\mathrm{~K}-\mathrm{W}\end{array}$ & $\begin{array}{l}\mathrm{F}=0.60 \\
p>0.05 \\
\text { ANOVA }\end{array}$ \\
\hline Position & 47 & 1 & $\begin{array}{l}\mathbf{\Lambda}-\mathrm{w} \\
p>0.05 \\
\mathrm{~K}-\mathrm{W}\end{array}$ & $\begin{array}{l}p>0.05 \\
\mathrm{~K}-\mathrm{W}\end{array}$ & $\begin{array}{l}p>0.05 \\
\mathrm{~K}-\mathrm{W}\end{array}$ & $\begin{array}{l}\mathrm{F}=13.40 \\
p<0.001 * * * \\
\text { ANOVA }\end{array}$ \\
\hline
\end{tabular}

Note. Abbreviation: $N$ - number of samples, $D F$ - degrees of freedom, ActM - active mycorrhizae density, NactM - nonactive mycorrhizae density, $<1 \mathrm{~mm}$ : root dry biomass $<1 \mathrm{~mm}$. 
Table 3 Mean values of individual factors

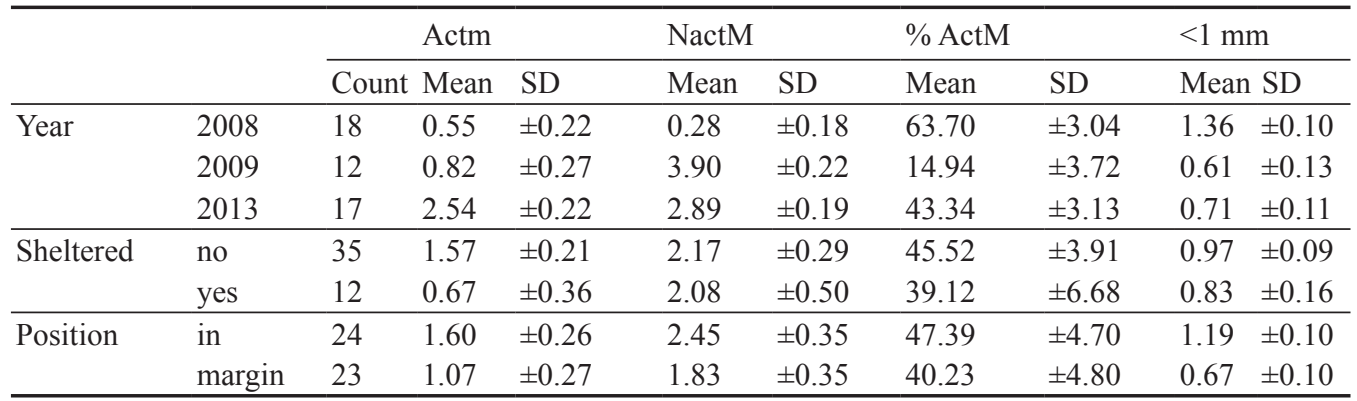

Note. The used abbreviation are similar to Table 2.

higher values for all mycorrhizal parameters than did those from the stand edge. Regarding active mycorrhizae, the difference between the stand edge and within the stand was not significant at the 0.05 level $(\mathrm{K}-\mathrm{W}: N=47, d f=1, p>$ 0.05 , Fig. 4$)$ but was nearly so $(p=0.051)$, and this does lend support to an assumption that this relationship is not random. These differences also were not significant for non-active mycorrhizae and active mycorrhizae proportion (K-W: $N=47, d f=1, p>0.05$, Fig. 4). For dry biomass of roots $<1 \mathrm{~mm}$, the difference between stand positions was significant (ANOVA: $N=47, d f=1, F=13.40, p<0.001$, Fig. 4).

\section{Discussion}

Statistically significant differences in all surveyed characteristics were ascertained across the observation period. The highest volume of root dry biomass (for roots $<1 \mathrm{~mm}$ in diameter) was found in 2008, the largest number of root tips without mycorrhizae (NactM) in 2009, and the largest number of active mycorrhizae (ActM) in 2013. Inasmuch as the most root biomass was determined in 2008, it probably occurred that root tips formed gradually, initially without mycorrhizae (or in the non-active form) and in subsequent years these root tips switched to the active stage followed by slow growth in active mycorrhizae density.
At the start of the monitored period, the total initial number of root tips was low and dominated by active mycorrhizae. Differences in the density, mycorrhizae proportion, and fine root weight across sampling years may, however, have been caused by natural fluctuations in stand conditions. Blasius et al. (1989), Pešková et al. (2007, 2011), Šrámek et al. (2009), and Pešková \& Soukup (2009) mention fluctuation of mycorrhizal characteristics in Norway spruce depending on season and habitat. We can presume that differing levels of drought stress at various locations or in various years could be a factor influencing mycorrhizae dynamics. Other authors had observed stable values in active mycorrhizae density and root dry biomass ( $<1 \mathrm{~mm}$ in diameter) in oak stands (Quercus robur L.) located close together (Fellner \& Pešková 1995, Pešková et al. 2013).

Greater active mycorrhizae density in the non-sheltered plots was apparent when mycorrhizal parameters related to the artificially induced drought stress were compared. On experimental plots with similar design, Lorenc (2012) also had determined significantly higher proportions of active mycorrhizae. Similar results were reported from oak stands by Pešková et al. (2013), who observed natural summer precipitation positively to influence tree health status and root system development. In addition, drought manifested in increased defoliation and decreased non-active 

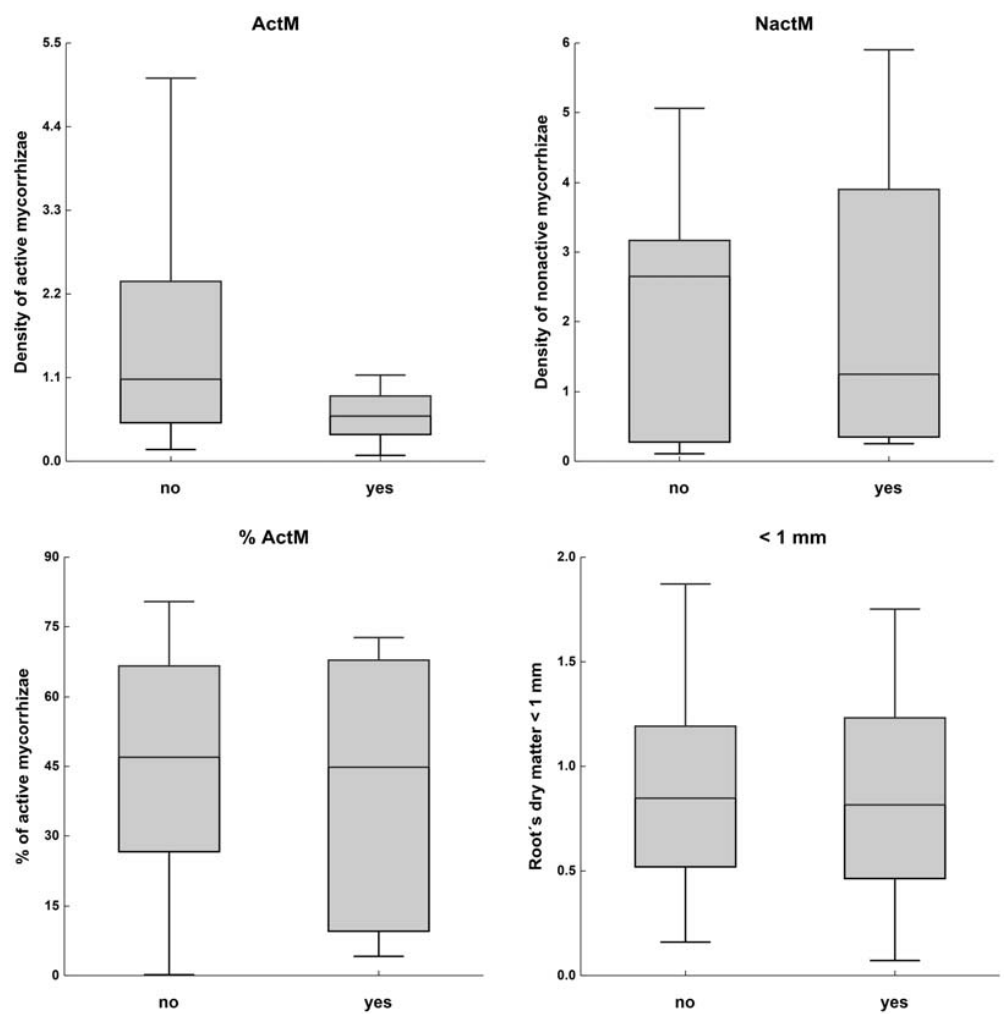

Figure 3 Box plots of mycorrhizal parameters and root dry matter $(<1 \mathrm{~mm})$ of trees sheltered to create drought conditions (yes) and not sheltered (no)

mycorrhizae density. In contrast to our results, Shi et al. (2002) recorded no significant impact on mycorrhizae density or the level of fungal colonization of the roots in seedlings of Fagus sylvatica L. from induced drought in two consecutive years.

Möttönen et al. (2001) recorded a negative impact on mycorrhizae density on the roots in Norway spruce vegetating in plastic containers from 9 days of irrigation. In another study, Möttönen et al. (2004) assessed the influence of one and two consecutive dry seasons followed by irrigation. In both cases, the drought had a negative impact on mycorrhizae, but the mycorrhizal relationship considerably improved after irrigating the seedlings which had been exposed to one dry season. In the case, too, of our experiment using shelter for rain exclusion, the artificially induced drought 252 stress was followed by mycorrhizae renewal (increased ActM). Similar conclusions had been reached by Nilsen et al. (1998) in their research on artificially planted spruce, where drought markedly and negatively influenced mycorrhizae proportions but among the recorded fungal morphotypes only the species Cenococcum geophilum Fr. was affected. In long-term field research, by contrast, Fransson et al. (2000) recorded no notable impact from watering Norway spruce on the total number of mycorrhizal tips or the occurrence of particular morphotypes. Palátová (2004) recorded in her first year of research a rather high negative drought impact on the mycorrhizal status of Norway spruce, as measured indirectly based on chitin content, but an improvement was registered in the subsequent period.

Recurrent severe defoliation as the result 

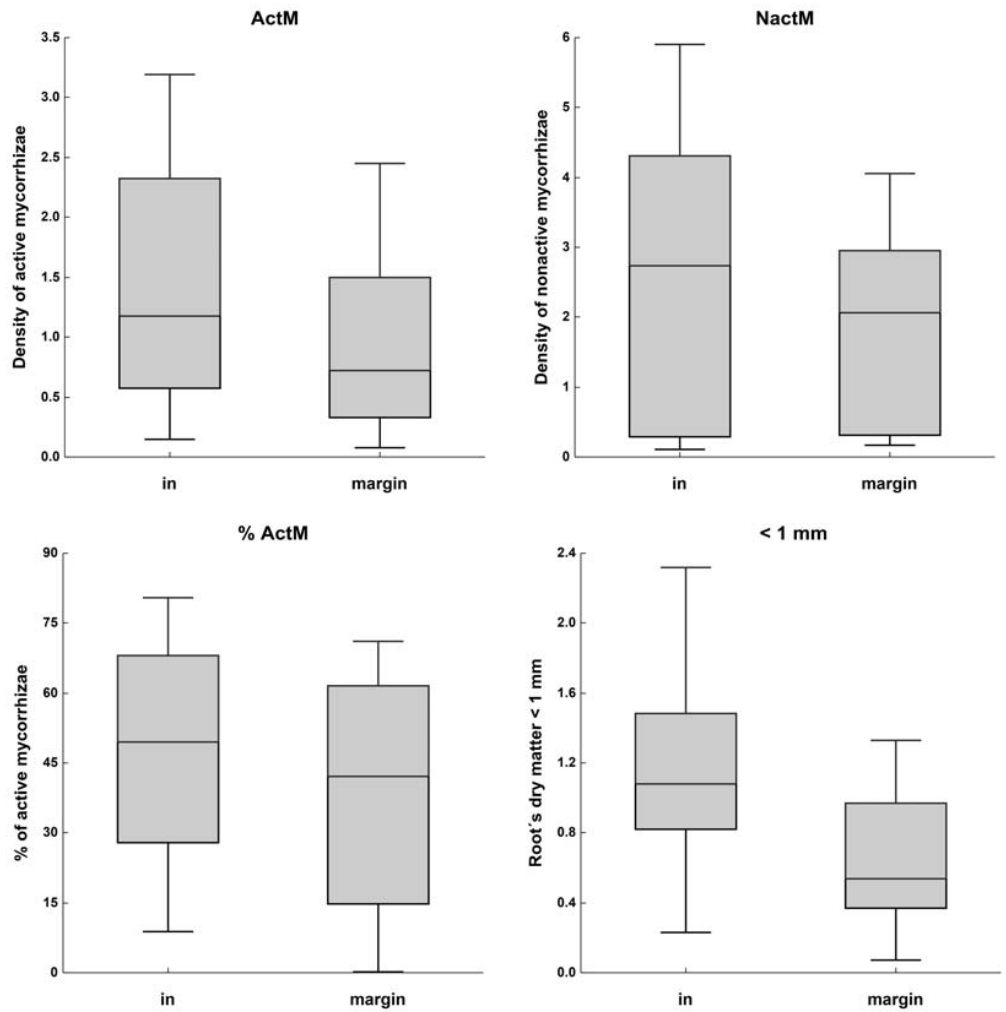

Figure 4 Box plots of mycorrhizal parameters and root dry matter $(<1 \mathrm{~mm})$ within the stand (in) - and on its edge - (margin)

of foliar insects may become an additional aggravating factor when assessing changes. This may in some way reduce mycorrhizal activity, as has clearly been demonstrated by Last et al. (1979) using artificial defoliation of young birches (Betula spp.). Acidification also has been shown to have a significant effect in decreasing the proportion of mycorrhizal roots in spruce at 88 years of age (Nowotny et al. 1996).

Our results do not indicate substantial differences when comparing the dry biomass weight of roots $<1 \mathrm{~mm}$ between stressed and non-stressed spruce. The results confirmed the conclusions of Gaul et al. (2008), who determined no significant effect in adult Norway spruce stands from 6 weeks of artificially induced drought on biomass weight of roots
$<2 \mathrm{~mm}$, although the spruces' mortality did increase significantly. Similar results were reported by Madji (2001), who showed in his paper that irrigation did not improve either fine roots production or their survival. In contrast, Feil et al. (1988) showed that drought had a large impact on the root system of spruce under natural and artificial conditions. In natural spruce stands, growth of the lowest-order roots was stimulated due to the effect of drought in late summer and early autumn on non-irrigated plots, while the elongation of higher-order roots was restrained. Palátová (2004) recorded a negative effect of drought on the weight of roots $<1 \mathrm{~mm}$ in 12-year-old stands of Norway spruce. The root systems of young trees may react more sensitively to drought stress, and it can be presumed that older trees have a higher 
degree of stability and so reactions following from stress may occur with a delay of as much as 1 year.

The influence of stand edge on the development of roots and mycorrhizae was another factor examined in the present study. Tree position on the edge was significantly negative when assessing the dry biomass of roots $<1 \mathrm{~mm}$ as opposed to sheltered plots. Additionally, the number of active mycorrhizae proved to be higher within the stand than at its edge. These results are inconsistent with similar studies. For example, Taskinen et al. (2003) assessed the impact of an artificial gap within an adult boreal spruce stand on root systems, dwarf shrubs, grasses, and herbs. In that case, tree roots located on the stand gap edge did not extend outside the stand gap. Čater \& Simončič (2010) investigated biomass of $F$. sylvatica seedlings in $P$. abies stands with different light regimes (under canopy, on the edge, in an open plot). Light had a significant positive effect on total biomass, root-shoot ratio, and specific root length of $F$. sylvatica fine roots (roots with diameters $<2 \mathrm{~mm}$ ) as well as on the specific leaf area of $P$. abies. With increasing light intensity and comparing $P$. abies and $F$. sylvatica, the root proportions for both fine and coarse roots shifted toward $F$. sylvatica. Goisser et al. (2013) investigated the response of young F. sylvatica to extreme and repeated summer drought along the natural gradient of light availability under a $P$. abies stand. Drought stress resulted in reduced plant growth, $\mathrm{CO}_{2}$ assimilation rate, and stomatal conductance, conversely, it brought about increased water-use efficiency, root-shoot ratio, rooting depth, and mean fine root diameter. The effect of ectomycorrhizal fungi on the architecture and nitrogen partitioning during drought in F. sylvatica seedlings under shade was investigated by Pena et al. (2013). Shade resulted in diminished root biomass production, thereby reducing the root-shoot ratio. Drought stress (pre-dawn water potential $-1.3 \mathrm{MPa}$ ) had no effect on biomass partitioning. Ectomycorrhiz- al fungi colonization had no significant effect on plant biomass, but the number of root tips as well as specific root lengths, were increased due to the formation of fine roots. Responses of ectomycorrhized plants to drought differed depending on light availability.

The majority of studies comparing the influence of placement on root biomass growth have been carried out on seedlings, often under laboratory conditions or in greenhouses. The research has focused primarily on $F$. sylvatica, which has different light requirements than does $P$. abies. The results generally demonstrate a positive effect of light on fine root biomass development. In our study, lower fine root biomass growth was determined on the stand edge than was found within the stand. This may have been caused by the stand's age and less suitable natural conditions for spruce at the stand's edge.

\section{Conclusions}

The present paper reports quantitative changes in roots and mycorrhizae induced by artificial drought stress. It establishes the important role of water in mycorrhizae development and changes. The values of the mycorrhizal characteristics showed pronounced annual changes. Active and non-active mycorrhizae increased after 2008 and reached a maximum in 2009 . A proportional decrease in active mycorrhizae and dry biomass of roots $<1 \mathrm{~mm}$ occurred during the same period, with the minima being observed in 2009 for all assessed variants. A statistically significant lower active mycorrhizae density was found in stressed trees. Other mycorrhizal parameters, and in particular non-active mycorrhizae density, were generally lower in stressed trees than in non-stressed tress, but the differences were not statistically significant. A noticeable difference in dry biomass of roots $<1 \mathrm{~mm}$ was observed between the stand edge and the inner stand, with root dry biomass higher within the stand. Although the values of 
active mycorrhizae were also higher inside the stand, these differences were not statistically significant. A comparison of the results of this work with the findings from similar research revealed that the effects of drought and stand placement on mycorrhizae and fine roots need not always be identical. Rather, they may depend on a number of additional factors, including drought duration and intensity, as well as mutual interactions. The monitored parameters display a complicated relationship which is difficult causally to identify in detail.

\section{Acknowledgements}

This research was conducted within National Agency for Agricultural Research of the Ministry of Agriculture of the Czech Republic (NAZV) - the project project QH 81136, Internal Grant Agency of Faculty of Forestry and Wood Sciences Czech University of Life Sciences in Prague - the projects GA FLD CZU 20134339 and GA FLD CZU A19/14, and GA FLD CZU A19/14, and the project of the Ministry of Agriculture of the Czech Republic Resolution RO0115 (reference number 5774/2015-MZE-17011). The authors would like to thank Gale A. Kirking at English Editorial Services, s.r.o. for linguistic improvements.

\section{References}

Blasius D., Kottke I., Oberwinkler F., 1989. Spatial and seasonal dynamics of ectomycorrhiza of Picea abies (L.) Karst. In the Black Forest. Agriculture, Ecosystems and Environmet 28: 27-30. DOI: 10.1016/01678809(90)90007-Z.

Caisová V., 1994. Hodnocení mykorhizace sazenic smrku pichlavého (Picea pungens) po aplikaci tekutého a suchého inokula lakovky (Laccaria proxima) []. Práce VÚLHM 79: 117/123.

Cairney J.W.G., 2012. Extramatrical mycelia of ectomycorrhizal fungi as moderators of carbon dynamics in forest soil. Soil Biology and Biochemistry 47: 198-208. DOI: 10.1016/j.soilbio. 2011.12.029.

Cudlin P., Kieliszewska-Rokicka B., Rudawska M., Gre- benc T., Alberton O., Lehto T., Bakker M.R., Børja I., Konôpka B., Leski T., Kraigher H., Kuyper T.W., 2007. Fine roots and ectomycorrhizas as indicators of environmental change. Plant Biosystems 141: 406-425. DOI: 10.1080/11263500701626028.

Čater M., Simončič P., 2010. Root distribution of underplanted European beech (Fagus sylvatica L.) below the canopy of a mature Norway spruce stand as a function of light. European Journal of Forest Research 129: 531539. DOI: $10.1007 / \mathrm{s} 10342-010-0356-5$.

Desprez-Loustau, M.L., Marcais, B., Nageleisen, L.M., Piou, D., Vannini, A., 2006. Interactive effets of drought and pathogens in forest trees. Annals of Forest Science, 63: 597-612. DOI: 10.1051/forest:2006040.

Domisch T., Finér R., Lehto T., 2002. Growth, carbohydrate and nutrient allocation of Scots pine seedlings after exposure to simulated low soil temperature in spring. Plant and Soil 246: 75-86. DOI: 10.1023/ A: 1021527716616.

Feil W., Köttke I., Oberwinkler F., 1988. The effect of drought on mycorrhizal production and very fine root system development of Norway spruce under natural and experimental conditions. Plant and Soil 108: 221231. DOI: $10.1007 / B F 02375652$.

Fellner R., Pešková V., 1995. Effects od industrial pollutants on ectomycorhizal relationships in temperate forests. Canadian Journal of Botany 73 (Suppl. 1): 13101315. DOI: 10.1139/b95-392. DOI: 10.1139/b95-392.

Fransson P.M.A., Taylor A.F.S, Finlay R.D., 2000. Effect of continuous optimal ferilization on belowground ectomycorrhizal community structure in a Norway spruce forest. Tree Physiology 20: 599-606. DOI: 10.1093/ treephys/20.9.599.

Gaul D., Hertel D., Borken W., Matzner E., Leuschner C., 2008. Effect of experimental drought on the fine root system of mature Norway spruce. Forest Ecology and Management 256: 1151-1159. DOI: 10.1016/ j.foreco.2008.06.016.

Goisser M., Zang U., Matzner E., Borken W., Häberle K.H. Matyssek R., 2013. Growth of juvenile beech (Fagus sylvatica L.) upon transplant into a wind-opened spruce stand of heterogeneous light and water conditions. Forest Ecology and Management 310: 110-119. DOI: 10.1016/j.foreco.2013.08.006.

Gryndler M., Baláž M., Hršelová H., Jansa J., Vosátko M., 2004. Mykorhizní symbióza, o soužití hub s kořeny rostlin [Mycorrhizal symbiosis, coexistence of fungi with plant roots]. Academie Praha, 366 p.

Hintze J.L., 2007. NCSS Help System. Kaysville, NCSS: $2823 \mathrm{p}$.

ISO/DIS 10390, 1992: Soil quality - Determination of $\mathrm{pH}$. International Organization for Standardization .

Kałucka I., Jagodziński A.A., 2013. Grzyby ektomykoryzowe w obliegu węgla w ekosystemach leśnych [Ectomycorrhizal fungi in the carbon cycle in forest ecosystems]. Sylwan 157(11): 817-830.

Kocourek R., 1991. Závislost odumírání smrku ztepilého (Picea abies (L.) Karst.) v imisních oblastech na eko- 
logických charakteristikách ektomykorrhizních symbióz. Kandidátská disertační práce. Ústav krajinné ekologie ČSAV, České Budějovice, 137 p.

Landeweert R., Veenman C., Kuyper T.W., Fritze H., Wernars K., Smit E., 2003. Quantification of ectomycorrhizal mycelium in soil by real-time PCR compared to conventional quantification techniques. FEMS Microbiology Ecology 45: 283-292. DOI: 10.1016/S01686496(03)00163-6.

Last F.T., Pelham J., Mason P.A., Ingleby K., 1979. Influence of leaves on sporophore production by fungi forming sheathing mycorrhizas with Betula spp. Nature 280: 168-169. DOI: $10.1038 / 280168 \mathrm{a} 0$.

Lehto T., Zwijazek J.J., 2011. Ectomycorrhizas and water relations of trees: a review. Mycorrhiza 21: 71-90. DOI: 10.1007/s00572-010-0348-9.

Lindner M., Garcia-Gonzalo J., Kolström M., Green T., Reguera R., Maroschek M., Seidl R., Lexer M.J., Netherer S., Schopf A., Kremer A., Delzon S., Barbati A., Marchetti M., Corona P., 2008. Impact of climate change of European Forests and options for adaptation. report to the European Commision Directorate-General for Agriculture and Rural Development, $173 \mathrm{p}$.

Lorenc F., 2012. Vliv sucha na růst mykorhiz u smrku ztepilého. Diplomová práce. Česká zemědělská univerzita v Praze []. Fakulta životního prostředí, Praha, 41 p.

Madji H., 2001. Changes in fine root production and longevity in relation to water and nutrient availability in a Norway spruce stand in northern Sweden. Tree Physiology 21: 1057-1061. DOI: 10.1093/treephys/21.14.1057.

Mehus H., 1986. Fruit body production of macrofungi in some North Norwegian forest types. Nordic Journal of Botany 6: 679-702. DOI: 10.1111/j.1756-1051.1986. tb00468.x.

Mejstř́ik V., 1988. Mykorhizní symbiózy [Mycorrhizal symbiosis]. Academia, Praha, 150 p.

Mejstř́k V., 1989. Ectomycorrhizas and forest decline. Agriculture, In: Mejstř́k V. (ed.): Ecological and Applied Aspects of Ecto- and Endomycorrhizal Associations 1, Ecosystems and Environmet 28. Praha: Academia: 325-337.

Mérian P., Lebourgeios F., 2011. Size-mediated climategrowth relationships in temperate forests: A multi-species analysis. Forest Ecology and Management, 261: 1382-1391. DOI: 10.1016/j.foreco.2011.01.019.

Möttönen M., Aphalo P.J., Lehto T., 2001. Role of boron in drought resistance in Norway spruce (Picea abies) seedlings. Tree Physiology 21(10): 673-681. DOI: 10.1093/treephys/ 21.10.673.

Möttönen M., Lehto T., Rita H., Aphalo P.J., 2004. Recovery of Norway spruce (Picea abies) seedlings from repeated drought as affected by boron nutrition. Trees 19: 213-223. DOI: 10.1007/s00468-004-0384-1.

Nilsen P., Børja I., Knutsen H., Brean R., 1998. Nitrogen and drought effects on ectomycorrhizae of Norway spruce (Picea abies L. (Karst.)). Plant and Soil 198: 179-184. DOI: 10.1023/A:1004399303192.

Nowotny I., Dähne J., Klingelhöfer D., Rothe G.M.,
1996. Effect of artificial soil acidification and liming on growth and nutrient status of mycorrhizal roots of Norway spruce (Picea abies (L.) Karst.). Plant and Soil 199: 29-40. DOI: 10.1023/A:1004265511068.

Økland, B., Berryman, A., 2004. Resource dynamic plays a key role in regional fluctuation of the spruce bark beetle Ips typographus. Agricultural and Forest Entomology, 6: 141-146. DOI: 10.1111/j.1461-9555.2004.00214.x.

Palátová E., 2004. Effect of increased nitogen depositions and drought stress on the development of young Norway spruce Picea abies (L.) Karst. Stands. Dendrobiology 51: 41-45.

Pena R., Simon J., Rennenberg H., Polle A., 2013. Ectomycorrhiza affect architecture and nitrogen partitioning of beech (Fagus sylvatica L.) seedlings under shade and drought. Environmental and Experimental Botany 87: 207-217. DOI: 10.1016/j.envexpbot. 2012.11.005.

Pešková V., Fellner R., Landa J., 2007. Nové údaje o ektotrofní stabilitě krkonošských horských smrčin: srovnání období let 1991-1995 a 2001-2005. In: Štursa J. Knapik R. (eds.), Geoekologické problémy Krkonoš. Sborník mezinárodní vědecké konference, říjen 2006, Svoboda nad Úpou Opera Corcontica, 44(2): 407 - 414.

Pešková V., Landa J., Soukup F., 2011. Findings regarding ectotrophic stability of Norway spruce forest of Krkonoše and Orlické Mts. based on mycorrhiza studies. Journal of Forest Science, 57(11): 500-513.

Pešková V., Soukup F., 2006. Houby vázané na kořenové systémy: metodické př́stupy ke studiu [Mushrooms bound root systems: methodological approaches to the study]. Review. Zprávy lesnického výzkumu 51(4): 279-286.

Pešková V., 2008. Houby na kořenech lesních dřevin. Mykorhizy [Mushrooms on the roots of forest trees. Mycorrhiza]. Lesnická práce 87(12): 4 p.

Pešková V., Soukup F., 2009. Srovnání rozvoje mykorhiz na krytých a exponovaných stanovištích horských smrčin [Compared development of mycorrhizas in sheltered and exposed sites spruce forests]. Zprávy lesnického výzkumu 54(3): 223-230.

Pešková V., Landa J., Modlinger R., 2013. Long term observation of mycorrhizal status and above-ground fungi fruiting body production in oak forest. Dendrobiology 69: 99-110. DOI: 10.12657/denbio.069.011.

Peterson R.L., Massicotte H.B., Melville H., 2004. Mycorrhizas: Anatomy and Cell Biology. - Ottawa, NRC Research Press, 173 p.

Pineda A., Dicke M., Pieterse C.M.J., Pozo M.J., 2013. Beneficial microbes in a changing environment: are they always helping plants to deal with insects? Functional Ecology 27: 574-586. DOI: 10.1111/1365-2435.12050.

Rosling A., Landeweert R., Lindahl B.D., Larsson K.-H., Kuyper T.W., Taylor A.F.S., Finlay R.D., 2003. Vertical distribution of ectomycorrhizal fungal taxa in a podzol soil profile. New Phytologist 159: 775-783. DOI: 10.1046/j.1469-8137.2003.00829.x.

Salerni E., Laganà A., Perini C., Loppi S., De Dominicis V., 2002. Effects of temperature and rainfall on fruit- 
ing of macrofungi in oak forests of the Mediterranean area. Israel Journal Plant Sciences 50: 189-198. DOI: 10.1560/GV8J-VPKL-UV98-WVU1.

Scattolin L., Montecchio L., Mosca E., Agerer R., 2008. Vertical distribution of ectomycorrhizal comunity in the top soil of Norway spruce stands. European Journal of Forest Research 127: 347-357. DOI: 10.1007/s10342008-0209-7.

Shi L., Guttenberger M., Kottke I., Hampp R., 2002. The effect of drought on mycorrhizas of Beech (Fagus sylvatica L.): ganges in community structure, and the content of carbohydrates and nitrogen storage bodies of the fungi. Mycorrhiza 12(6): 303-311. DOI: 10.1007s00572-002-0197-2.

Šrámek V., Soukup F., Slodičák M., Balcar V., Hellebrantová K., Lachmanová Z., Novák J., Novotný R., Pešková V., Vícha Z., Vejpustková M.,Vortelová L., Lomský B., 2009. Chřadnutí lesních porostů na LS Jablunkov - určení komplexu příčin poškození a návrh opatření na revitalizaci lesa. Grantová služba LČR 05/09: $100 \mathrm{p}$.

Taskinen O., Ilvesniemi H., Kuuluvainen T., Leinonen K., 2003. Response of fine roots to an experimental gap in a boreal Picea abies forest. Plant and Soil 255: 503-512. DOI: 10.1023/ A:1026077830097. 